\title{
Trachyplax arctica, a new multiplated problematic fossil from the lower Cambrian of North Greenland
}

Cecilia M. Larsson, John S. Peel, and Anette E.S. Högström

Acta Palaeontologica Polonica 54 (3), 2009: 513-523 doi: http://dx.doi.org/10.4202/app.2009.0026

A new scleritome-bearing organism with eight sclerite types, Trachyplax arctica gen. et sp. nov., is described from the lower Cambrian Paralledal Formation of North Greenland. The originally calcareous sclerites are now silicified; no microstructures are preserved. The dominant sclerite type ( $A$; maximum dimension $19.3 \mathrm{~mm}$ ) is bilaterally symmetrical, strongly arched, with an oval shield showing co-marginal growth lines and a projecting rostrum with prominent radial ornamentation. A similar sclerite morphology can be identified in Silurian-Carboniferous multiplacophoran molluscs but the remaining sclerite types, which also display a combination of concentric and radial ornamentation, find no clear equivalents. Two models for scleritome reconstruction are presented, based on the relative abundance of the sclerites, but neither promotes a satisfactory assignment to a higher taxon. Despite the morphological dissimilarities, possibly reflecting the age discrepancy, reference to the Multiplacophora is most attractive and entails a substantial extension of the known geological range of that group.

Key words: Trachyplax, Problematica, sclerites, scleritome, Multiplacophora, Cambrian, Greenland.

Cecilia M. Larsson [cecilia.larsson@geo.uu.se], John S. Peel [john.peel@pal.uu.se ], and Anette E.S. Högström [anette.hogstrom@pal.uu.se], Department of Earth Sciences, Palaeobiology, Uppsala University, Villavägen 16, SE-752 36 Uppsala, Sweden.

This is an open-access article distributed under the terms of the Creative Commons Attribution License (for details please see creativecommons.org), which permits unrestricted use, distribution, and reproduction in any medium, provided the original author and source are credited. 
